\title{
Late Neonatal Mortality at Teaching Hospital of Brazzaville (Congo)
}

\author{
Gaston Ekouya Bowassa',2*, Engoba Moyen', Néli Yvette Ngakengni, ${ }^{1,2}$, Annie Rachelle Okoko1 \\ ${ }^{1}$ Faculty of Health Sciences, Marien NGOUABI University, Brazzaville, Congo \\ ${ }^{2}$ Department of Neonatology, University Hospital of Brazzaville, Brazzaville, Congo \\ Email: *ekouyabg@yahoo.fr
}

How to cite this paper: Bowassa, G.E., Moyen, E., Ngakengni, N.Y. and Okoko, A.R. (2020) Late Neonatal Mortality at Teaching Hospital of Brazzaville (Congo). Open Journal of Pediatrics, 10, 30-35. https://doi.org/10.4236/ojped.2020.101003

Received: November 26, 2019

Accepted: January 16, 2020

Published: January 19, 2020

Copyright (c) 2020 by author(s) and Scientific Research Publishing Inc. This work is licensed under the Creative Commons Attribution International License (CC BY 4.0).

http://creativecommons.org/licenses/by/4.0/ (c) (i) Open Access

\begin{abstract}
Background: Neonatal mortality is a major public health problem. Its reduction is one of the targets of the objectives for sustainable development. Objectives: To determine the frequency of late neonatal mortality, to determine the causes of death and to identify the factors associated with late neonatal mortality at Brazzaville University Hospital. Patients and methods: This was a descriptive and analytical study conducted in the neonatal department of the Brazzaville University Hospital from 1 January to 30 June 2018. It concerned all newborns admitted to the service and died between 7th and 28th day of life. The variables studied were epidemiological, clinical and evolutionary. For the study of the factors associated with late mortality, we compared the deceased newborns with those hospitalized in the service whose stay was at least seven days. The materiality threshold was $5 \%$. Results: During the study period, 697 newborns were admitted to the service, 286 (41\%) died, 79 (27.6\%) on the seventh day or beyond. The median age at admission was one hour. These were male (44.3\%) and female (55.7\%) newborns. The causes of death were prematurity $(50.7 \%)$, neonatal infection $(36.7 \%)$, perinatal asphyxia (6.3\%) and others (6.3\%). The mean age at death was $13.5 \pm 6.4$ days (range: 7 and 28 days). Prematurity OR $=3.62$ (95\% CI: $1.2-10.6)$ is the factor associated with late mortality. Conclusion: Reducing late neonatal mortality requires the implementation of measures to improve the human and material capacities of the service.
\end{abstract}

\section{Keywords}

Mortality, Late, Newborns, Prematurity

\section{Introduction}

With 2.8 million deaths, neonatal mortality is a major public health problem [1] 
[2]. Southeast Asia and sub-Saharan Africa are the most affected regions of the world [1]. In the Congo, the neonatal mortality rate is 16 per 1000 live births [1]. Neonatal mortality accounts for $44 \%$ of the mortality of children under 5 [3].

Neonatal mortality is said to be early when death occurs in the first six days of life and late in the seventh to the twenty-eighth day.

In the vast majority of cases, the occurrence of newborn deaths is reported in the first six days [4] [5] [6] [7]. Late mortality is poorly documented. Worldwide, it accounts for $24.2 \%$ of global neonatal mortality [8].

Reducing neonatal mortality to less than 10 per 1000 live births is a target of the goals for sustainable development [3] [4]. It requires that the causes and factors associated with the newborn's death be known, both in the early and late onset [8]. But, whether it is early or late causes death diverge [8] [9]. Also, it seemed useful to us to carry out this study on the late neonatal mortality.

The objective of this study is to determine the frequency of late mortality in the Neonatology Department of the Brazzaville University Hospital, to determine the causes of death and to identify factors associated with late infant mortality

\section{Patients and Methods}

This was a descriptive and analytical study conducted in the neonatal department of the CHU Brazzaville from January 1 to June 30, 2018 (6 months). This service is the main one in the city; it welcomes the newborns coming from the maternity of the same $\mathrm{CHU}$ and other maternities of the city. The study involved neonates hospitalized in the department during the study period. Those who died between the 7th and the 28th day of civil age were included.

The variables studied were the age, sex, the delivery route, the source, the clinical signs at admission and the causes of death.

Excel and Epi Info 7 software enabled data entry and analysis. For the study of the factors associated with late mortality, we compared the deceased newborns with those hospitalized in the service whose stay was at least seven days. The ANOVA test, the chi-square test, and the Odds Ratio (OR) with a 95\% confidence interval were used for univariate analysis to compare means and proportions. All variables that were found to be associated during the univariate analysis were selected for multivariate analysis. We performed a logistic regression to adjust the confounds. The materiality threshold was $5 \%$.

For ethical considerations, we have taken into account the recommendations of the Helsinki Protocol.

\section{Results}

During the study period, 697 newborns were admitted to the service, 286 (41\%) died, $79(27.6 \%)$ on the seventh day or beyond. The median age at admission was one hour. There were 35 (44.3\%) male and 44 (55.7\%) female births, a sex ratio of 0.8 . Delivery was vaginal in $66(83.5 \%)$ cases and by caesarean section in 
$13(16.5 \%)$ cases. The birth weight was $1689.8 \pm 730.7 \mathrm{~g}$ (range 750 to $4600 \mathrm{~g}$ ). Newborns with low birth weight were 65 (82.3\%). Newborns were transferred from another hospital in the city in $34(43 \%)$ cases. They came from: maternity hospital: 34 (43\%); another public hospital in the city: 30 (38\%); a private clinic: 4 (5.1\%); home: 11 (13.9\%).

The clinical signs at admission are shown in Table 1.

The gestational age was $31.4+/-3.8$ weeks (range 25 - 40 weeks). The premature babies were 66 or $83.5 \%$. The causes of death are reported in Figure 1 .

The mean age at death was $13.5 \pm 6.4$ days (range: 7 and 28 days). Factors associated with late mortality are reported in Table 2 and Table 3.

\section{Discussion}

Reducing neonatal mortality by 2030 is a challenge for developing countries, particularly those in sub-Saharan Africa. Achieving this objective requires knowledge of the causes and factors involved in neonatal mortality in a global way but also in its various components. This study specifically devoted to late neonatal mortality in hospitals is part of this approach. However, as this study has as a limitation, the small size of our population because of the short duration of data collection. The Neonatology Department of the University Hospital was the setting for the study. This service is almost the only one in the city, allowing us to extrapolate our results to all health centers in the city.

We reported a late mortality rate of $27.6 \%$. This frequency is higher than those of Mekonnen in Ethiopia (2.3\%) and Bezzaoucha in Algeria (16.6\%) [4] [10]. Kedy Koum in Douala [11], which reports late mortality on all admissions and not on all deaths as we did, at a rate of $16.6 \%$. In Ivory Cost, Mutombo [12] has a late neonatal mortality rate of $7.44 \%$. These disparities in our observations can be justified by the differences in the health systems of our countries and the specificities of the Neonatology units. So, the uniqueness of our service in the city, justifies admitting all newborns in vital distress, explaining the high rate of death.

Table 1. Clinical signs at admission*.

\begin{tabular}{ccc}
\hline & N & $\%$ \\
\hline Hypotonia & 73 & 92.4 \\
Respiratory distress & 56 & 70.9 \\
Disorders of consciousness & 19 & 24.1 \\
Jaundice & 8 & 10.1 \\
Fever & 7 & 8.9 \\
Seizure & 6 & 7.6 \\
Cutaneous pallor & 5 & 6.3 \\
\hline
\end{tabular}

*A patient may have multiple signs. 


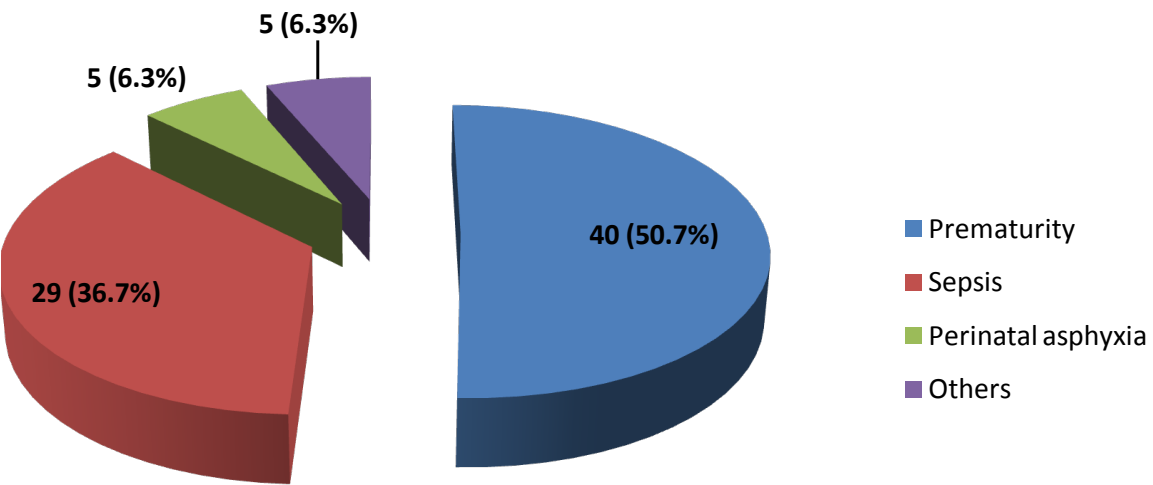

Figure 1. Causes of death.

Table 2. Univariate analysis.

\begin{tabular}{cccccc}
\hline & \multicolumn{2}{c}{ Death } & & \\
\cline { 2 - 3 } & Yes (\%) & No (\%) & & IC (95\%) & P \\
\hline Vaginal delivery & $66(83.5)$ & $191(73.5)$ & 1.8 & $0.9-3.5$ & 0.09 \\
Multiple pregnancy & $23(29.1)$ & $46(17.7)$ & 1.9 & $1.1-3.4$ & $0.04^{*}$ \\
Resuscitation & $13(16.5)$ & $69(26.4)$ & 0.5 & $0.3-1$ & 0.09 \\
Low birth weight & $65(82.3)$ & $124(47.7)$ & 5.1 & $2.7-9.5$ & $10^{-7 *}$ \\
Referred newborn & $34(50)$ & $119(53.9)$ & 0.9 & $0.5-1.5$ & 0.7 \\
Respiratory distress & $56(70.9)$ & $154(59.2)$ & 1.6 & $0.9-2.8$ & 0.08 \\
Seizure & $6(7.6)$ & $35(13.5)$ & 0.5 & $0.2-1.3$ & 0.2 \\
Cutaneous pallor & $5(6.3)$ & $12(4.6)$ & 1.4 & $0.4-4.1$ & 0.5 \\
Prematurity & $66(83.5)$ & $121(46.5)$ & 5.8 & $3-11.1$ & $10^{-10 *}$ \\
Sepsis & $29(36.7)$ & $80(30.7)$ & 1.3 & $0.7-2.2$ & 0.7 \\
\hline
\end{tabular}

Table 3. Multivariate analysis.

\begin{tabular}{ccccccc}
\hline & ORa & IC (95\%) & Coeff & SE & Z-statistic & P \\
\hline Low birth weight & 1.78 & $0.6-5.1$ & 0.576 & 0.53 & 1.0743 & 0.3 \\
Multiple pregnancy & 0.99 & $0.5-1.8$ & -0.0018 & 0.31 & -0.0057 & 0.9 \\
Prematurity & 3.62 & $1.2-10.6$ & 1.286 & 0.54 & 2.3480 & 0.01 \\
\hline
\end{tabular}

The classic causes of neonatal mortality as a whole were also pinned on late neonatal mortality in Brazzaville. But prematurity occupies a special place, because of its frequency, $83.5 \%$ of our population, its implication $50.7 \%$ of the causes of death and the only factor associated with mortality. In the Congo and other developing countries, prematurity is a real public health problem and is a cause and a major factor associated with death in the first 28 days of life [5] [13] [14].

Neonatal infection, reported as the leading cause of late mortality by Oza in 194 countries and Bezzaoucha in Blida (Algeria) [8] [10], is second in Brazzaville. Bezzaoucha et al. justify the preponderant place of infection in late mortal- 
ity in Blida due to the high frequency of nosocomial infections [10]. In our series, apart from nosocomial infections, the usual bacterial resistance to antibiotics observed in the department [15] can also explain the no less important role of neonatal infection.

Prematurity is the only associated factor found in multivariate analysis. The significant mortality of the premature infant is due to the susceptibility to infections and immaturity, especially respiratory, but also to the difficulties of breeding in Neonatology units in Africa south of the Sahara, which is poorly equipped [10] [12].

\section{Conclusion}

Representing just over a quarter of overall mortality, late neonatal mortality is a concern in the neonatology department of the Brazzaville University Hospital. Prematurity and its complications are a great provider. The reduction of the late mortality requires that the human and material means necessary to the management of the premature infant and to the fight against the nosocomial infections should be implemented.

\section{Conflicts of Interest}

The authors declare no conflicts of interest regarding the publication of this paper.

\section{References}

[1] United Nations Inter-agency Group for Child Mortality Estimation (UN IGME) (2017) Levels and Trends in Child Mortality: Report 2017. Estimates Developed by the UN Inter-Agency Group for Child Mortality Estimation. UNICEF, New York.

[2] Lawn, J.E., Blencove, H., Oza, S., You, D., Lee, A.C., Waiswa, P., et al. (2014) Every Newborn: Progress, Priorities, and Potential beyond Survival. The Lancet, 384, 189-205. https://doi.org/10.1016/S0140-6736(14)60496-7

[3] OMS, UNICEF (2014) Chaque nouveau-né: Plan d'action pour mettre fin aux décès évitables, résumé d'orientation. Genève.

[4] Mekonnen, T., Tenu, T., Aklilu, T. and Abera, T. (2018) Assessment of Neonatal Death and Causes among Admitted Neonates in Neonatal Intensive Care Unit of Mizan Tepi University Teaching Hospital, Bench Maji Zone, South-West Ethiopia, 2018. Clinical Mothers and Child Health, 15, 4. https://doi.org/10.4172/2090-7214

[5] Vieirin Nzame, Y., Maladjou Kondjo, J., Gahouma, D., Imboua, L., Mongi, P. and Moussavou, A. (2010) Neonatal Mortality: A Survey in Libreville and Owendo. Archives de Pédiatrie, 17, 179-180. https://doi.org/10.1016/j.arcped.2009.11.002

[6] Kouéta, F., Yé, D., Dao, L., Néboua, D. and Sawadogo, A. (2007) Morbidité et mortalité néonatales de 2002 à 2006 au Centre hospitalier universitaire pédiatrique Charles de Gaulle de Ouagadougou (Burkina Faso). Cahiers Santé, 17, 187-191.

[7] Djadou, K.-E., Azouma, D., Yable, G., Dakey, G., Sanda, P., Dokounor, D., et al. (2006) Neonatal Mortality at Tseve Hospital (Togo). Archives de Pédiatrie, 13, 1156. https://doi.org/10.1016/j.arcped.2006.05.001

[8] Oza, S., Lawn, J.E., Hogan, D.R., Mathers, C. and Cousens, S.N. (2015) Neonatal 
Cause-of-Death Estimates for the Early and Late Neonatal Periods for 194 Countries: 2000-2013. Bulletin of the World Health Organization, 93, 19-28.

https://doi.org/10.2471/BLT.14.139790

[9] Chowdhury, H.R., Thompson, S., Ali, M., Alam, N., Yunus, M. and Streatfield, P.K. (2010) Causes of Neonatal Deaths in a Rural Subdistrict of Bangladesh: Implications for Intervention. Journal of Health and Population Nutrition, 28, 375-382. https://doi.org/10.3329/jhpn.v28i4.6044

[10] Bezzaoucha, A., El Kebboub, A. and Aliche, A. (2010) Evolution of Neonatal Mortality at the Blida University Teaching Hospital (Algeria) between 1999 and 2006. Bulletin de la Société de Pathologie Exotique, 103, 29-36.

https://doi.org/10.1007/s13149-009-0001-Z

[11] Kedy Koum, D.C., Essomba, N.E., Ngaba, G.P., Sintat, S., Koki Ndombo, P. and Coppieters, Y. (2015) Morbidité et facteurs de risque de mortalité néonatale dans un hôpital de référence de Douala. Pan African Medical Journal, 20, 258. https://doi.org/10.11604/pamj.2015.20.258.5648

[12] Mutombo, T. (1997) Difficulté d'améliorer le taux de mortalité néonatale en milieu rural. Médecine d Afrique Noire, 44, 658-660.

[13] Kedy Koum, D., Exhenry, C., Penda, C.-I., Nzima Nzima, V. and Pfister, R.E. (2014) Neonatal Morbidity and Mortality in a Low Resource Urban District Hospital of Douala, Cameroon. Archives de Pédiatrie, 21, 147-156. https://doi.org/10.1016/j.arcped.2013.11.014

[14] Mulongo Mbarambara, P., Kajemba Namukuru, F., Kyambikwa Bisangamo, C. and Mansuka, M. (2015) Factors Associated with Perinatal Mortality at the Dr Rau/Ciriri Hospital. Journal de Pédiatrie et de Puériculture, 28, 109-113. https://doi.org/10.1016/j.jpp.2015.02.010

[15] Ekouya Bowassa, G., Ontsira-Ngoyi, E.N., Okoko, A.R., Kimpolo Tsiba, H.G., Oko APG, Moyen, E., et al. (2015) Bacteriology of Early Neonatal Infection in Brazzaville (Congo). Archives de Pédiatrie, 22, 1099-1100. https://doi.org/10.1016/j.arcped.2015.07.004 